\title{
Influence of Phosphate Fertilizers on Pineapple Yields
}

\author{
G. Samuels, P. Landrau, Jr., and S. Alers Alers ${ }^{1}$
}

\section{INTRODUCTION}

Nitrogen and potassium have long been recognized as required fertilizer elements for high yields and good quality in the commercial growing of pineapples. Without nitrogen fertilizers, yields are poor and plant growth suffers in general. The omission of potash fertilizers may not always reduce pineapple yields, but the flavor and color of the pineapple generally suffers. However, the case for phosphate fertilizers is not as clear-cut. Although used by pineapple growers, phosphate fertilizers generally have had no decisive influence on the crop in controlled fertilizer experiments.

As early as 1925, Henricksen $(2)^{2}$ found that phosphate fertilizers used by the growers at commercial rates were giving lower pineapple yields per acre than when no phosphate were applied. Since then other workers, such as Pennock (4), González Ríos (1), and Schapelle (6), have all obtained lower yields of pineapples when phosphate fertilizers were applied.

All of this pineapple work has been carried out with the Red Spanish variety grown commercially in Puerto Rico. Nightingale (3), in Hawaii, found that, for the Smooth Cayenne variety, yields either were not increased or were reduced if phosphate fertilizers were added to the soil around pineapples which had a sufficient phosphate supply. Yield increases were obtained only where plants low in phosphorus were fertilized with phosphate just prior to and during blossom-bud differentiation.

\section{PROCEDURES}

To study the influence of phosphate fertilizers on pineapple yields, data were utilized from a series of pineapple-fertilizer experiments with the Red Spanish variety established throughout the pineapple-growing area of Puerto Rico. Detailed procedures as to design and treatments were given in a previous article (5). In these experiments, 28 pounds of $\mathrm{P}_{2} \mathrm{O}_{5}$ per acre per application was applied in from one to four applications at 4-month intervals, starting at time of planting. This was done in such a manner that rates of $0,28,56,84$, and 112 pounds $\mathrm{P}_{2} \mathrm{O}_{5}$ per acre per crop were applied. Nitrogen and potash were added to all treatments at optimum rates.

${ }^{1}$ Agronomist, Associate Agronomist, and Research Assistant in Agronomy, respectively, Agricultural Experiment Station, University of Puerto Rico, Río Piedras, P. R. The authors wish to thank H. Gandia-Diaz, Associate Horticulturist, in charge of the Corozal Substation, for his aid in the field work.

${ }^{2}$ Numbers in parentheses refer to Literature Cited, p. 223. 
Two experiments, one with a plant crop and a ratoon and another with a plant crop only, were grown at the Corozal Substation on a Lares clay. This is a medium-friable acid clay occurring in terrace formations from materials washed from the lower Tertiary clays and shales. The soil $\mathrm{pH}$

TABLE 1.-Mean yields of Red Spanish pineapples grown at various phosphate levels used in 1 to 4 applications

\begin{tabular}{|c|c|c|c|c|c|}
\hline \multirow{2}{*}{ Treatment ${ }^{1}$} & \multicolumn{4}{|c|}{$\begin{array}{l}\text { Mean yield of pineapples per acre for the number and } \\
\text { rate of phosphate }\left(\mathrm{P}_{2} \mathrm{O}_{5}\right) \text { applications per acre indicated- }\end{array}$} & \multirow{2}{*}{ Mean } \\
\hline & $\begin{array}{l}1 \text { application, } \\
28 \text { pounds } \\
\mathrm{P}_{2} \mathrm{O}_{5}\end{array}$ & $\begin{array}{l}2 \text { applica- } \\
\text { tions, } 56 \\
\text { pounds } \mathrm{P}_{2} \mathrm{O}_{5}\end{array}$ & $\begin{array}{l}3 \text { applica- } \\
\text { tions, } 84 \\
\text { pounds } \mathrm{P}_{2} \mathrm{O}_{5}\end{array}$ & $\begin{array}{l}4 \text { applica- } \\
\text { tions, } 112 \\
\text { pounds } \mathrm{P}_{2} \mathrm{O}_{5}\end{array}$ & \\
\hline \multicolumn{6}{|c|}{ Corozal, experiment 1, plant crop (1953-54) } \\
\hline $\begin{array}{l}\text { No phosphate........... } \\
\text { Phosphate. . . . . . } \ldots \ldots \ldots\end{array}$ & $\begin{array}{l}10.7 \\
12.5\end{array}$ & $\begin{array}{l}12.2 \\
13.7\end{array}$ & $\begin{array}{l}15.2 \\
15.0\end{array}$ & $\begin{array}{l}14.2 \\
13.5\end{array}$ & $\begin{array}{l}13.1 \\
13.7\end{array}$ \\
\hline L.S.D. at 5 percent. . . . . . & 2.0 & 2.0 & 2.0 & 2.0 & 0.7 \\
\hline
\end{tabular}

Corozal, experiment 1 , ratoon crop $(1954-55)$

\begin{tabular}{|c|c|c|c|c|c|}
\hline $\begin{array}{l}\text { No phosphate............... } \\
\text { Phosphate................ }\end{array}$ & $\begin{array}{r}12.5 \\
8.6\end{array}$ & $\begin{array}{r}8.8 \\
11.3\end{array}$ & $\begin{array}{r}12.7 \\
9.8\end{array}$ & $\begin{array}{r}11.7 \\
9.0\end{array}$ & $\begin{array}{r}11.4 \\
9.7\end{array}$ \\
\hline L.S.D. at 5 percent. & 2.9 & 2.9 & 2.9 & 2.9 & 1.5 \\
\hline
\end{tabular}

Corozal, experiment 2 plant crop (1954-55)

\begin{tabular}{|c|c|c|c|c|c|}
\hline $\begin{array}{l}\text { No phosphate............... } \\
\text { Phosphate. . . . }\end{array}$ & $\begin{array}{l}8.3 \\
8.4\end{array}$ & $\begin{array}{l}7.8 \\
9.8\end{array}$ & $\begin{array}{l}11.0 \\
10.4\end{array}$ & $\begin{array}{l}12.6 \\
11.6\end{array}$ & $\begin{array}{l}10.0 \\
10.1\end{array}$ \\
\hline L.S.D. at 5 percent. . . . . . & 2.1 & 2.1 & 2.1 & 2.1 & 1.0 \\
\hline
\end{tabular}

Manati, plant crop (1954-55)

\begin{tabular}{|c|c|c|c|c|c|}
\hline $\begin{array}{l}\text { No phosphate.............. } \\
\text { Phosphate } \ldots \ldots \ldots \ldots \ldots \ldots\end{array}$ & $\begin{array}{l}10.1 \\
13.2\end{array}$ & $\begin{array}{l}16.2 \\
12.0\end{array}$ & $\begin{array}{l}15.6 \\
15.3\end{array}$ & $\begin{array}{l}16.3 \\
14.6\end{array}$ & $\begin{array}{l}14.6 \\
13.8\end{array}$ \\
\hline L.S.D. at 5 percent. . . & 6.0 & 6.0 & 6.0 & 6.0 & 2.4 \\
\hline
\end{tabular}

Mean of all experiments

\begin{tabular}{l|c|c|c|c|c}
\hline $\begin{array}{l}\text { No phosphate............ } \\
\text { Phosphate............... }\end{array}$ & $\begin{array}{l}10.4 \\
10.7\end{array}$ & $\begin{array}{c}11.3 \\
11.7\end{array}$ & $\begin{array}{c}13.6 \\
12.6\end{array}$ & $\begin{array}{l}13.7 \\
12.2\end{array}$ & $\begin{array}{c}12.3 \\
11.8\end{array}$ \\
\hline L.S.D. at 5 percent........ & 3.3 & 3.3 & 3.3 & 3.3 & 1.5 \\
\hline
\end{tabular}

${ }^{1}$ All treatments received nitrogen and potash fertilizers. 
was 4.8. Another experiment was made on a plant crop grown on a Bayamón sandy clay loam at the Florida farm of the Land Authority of Puerto Rico at Manatí.

\section{RESULTS}

The results of the phosphate treatments are given in table 1 . In only one case (Corozal experiment 1, plant crop, first application of 28 pounds $\mathrm{P}_{2} \mathrm{O}_{5}$ ), did yields increase almost significantly when phosphates were used. In general, there were no significant yield increases from the use of phosphate fertilizers on pineapples. The means of all the experiments showed a steady decrease in yield with increasing amounts of phosphate applied after the second application. For the treatments with 28 and 56 pounds of $\mathrm{P}_{2} \mathrm{O}_{5}$ per acre, applied up to 4 months after planting, some increases in yields were obtained in all cases except two. For the treatments with 84 and 112 pounds of $\mathrm{P}_{2} \mathrm{O}_{5}$ per acre, applied 8 and 12 months after planting, decreases in yields were obtained in all cases.

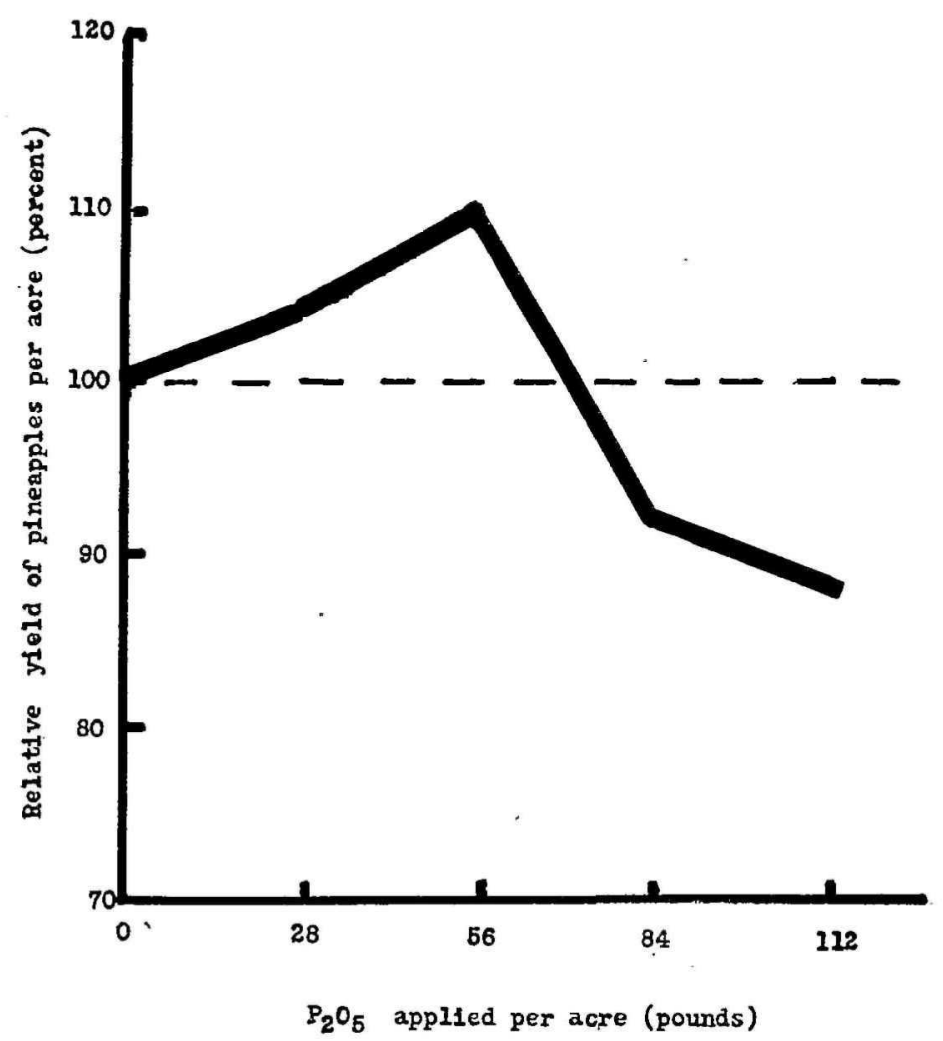

Frg. 1.-The influence of phosphate applications on relative yields of pineapples. 
These factors were plotted graphically to evaluate the relationship between phosphate additions to the soil and pineapple yields. In order to compare all experiments on the same basis, the yields in tons of pineapples per acre were changed to relative yields. The relative yield was calculated using the yield with no phosphate applied as 100. The influence of rates of phosphate application on these relative yields is shown graphically in figure 1 . We see that 28 pounds of $\mathrm{P}_{2} \mathrm{O}_{5}$ increased yields only 4 percent, to 104 ; and with 56 pounds of $\mathrm{P}_{2} \mathrm{O}_{5}$ they rose to 110 . However, with 84 pounds of $\mathrm{P}_{2} \mathrm{O}_{5}$, yields dropped to 92 , or 8 percent lower than when no $\mathrm{P}_{2} \mathrm{O}_{5}$ was used. Finally where 112 pounds of $\mathrm{P}_{2} \mathrm{O}_{5}$ were used yields declined to 88 , or 12 percent less than where no phosphate were used.

From these experimental data, the maximum quantity of $\mathrm{P}_{2} \mathrm{O}_{5}$ per acre which would not depress pineapple yields was 56 pounds. This safe limit, of course, applies only to the experimental data, but inasmuch as previous research has shown depressed yields with phosphate applications averaging over 100 pounds of $\mathrm{P}_{2} \mathrm{O}_{5}$ per acre, the pineapple grower should be very cautious in applying phosphate fertilizers to his plants. Although small quantities are not harmful and may prove beneficial, applications now used by the farmer with mixed commercial fertilizers are many times over the safe limit and may depress pineapple yields.

\section{DISCUSSION}

To the inquisitive mind, the question arises as to why phosphate applications depress pineapple yields, even when used at relatively low rates as compared to applications made to other crops. Nightingale, working with pineapples in Hawaii, felt that when supplies of phosphate to the pineapple plant were adequate, further additions of phosphate fertilizers served only to create an unbalanced nutrient level in which the phosphate depressed the influence of nitrates (3). If this condition were coupled with high carbohydrate reserves in the plant, the phosphate additions depressed the muchneeded nitrates to the extent that yields actually suffered. He also stated that, under conditions of low carbohydrate reserves, when nitrate needs are lower, the depressing effect of the phosphate may actually be beneficial and help increase yields. For these reasons, phosphate additions under Hawaiian conditions have produced a mixed response on yields. When Nightingale critically evaluated the carbohydrate, nitrate, and phosphorus levels at the crucial period just prior to and during blossom-bud differentiation, he could determine when phosphate fertilizers were needed. If carbohydrate and nitrate reserves were not high and phosphorus levels were low, additions of phosphate fertilizers proved of no value for increasing pineapple yields.

Another point to be considered in relation to phosphorus is its influence 
on the time of fruiting. It has been shown that heavy applications of phosphate hasten the maturity of other crops (3). This ripening effect has been observed many times by the authors where high phosphate has been used on pineapples. Pennock (4) found that 60 pounds of $\mathrm{P}_{2} \mathrm{O}_{5}$ per acre depressed yields 5 percent with Red Spanish pineapples growing on a Bayamón silty clay loam at Arecibo. This lowered yield was due mainly to a change in size of fruit. Where phosphates were used there was a significant increase in the number of culls or small fruits unfit for market. It appears that the addition of phosphate hastened maturity and produced smaller fruits.

At present our pineapple growers use too much phosphate fertilizers. Although they have decreased somewhat the quantity used, rates are still too high in many cases - for example 172 tons of $\mathrm{P}_{2} \mathrm{O}_{5}$, equivalent to 860 tons of superphosphate (20 percent $\mathrm{P}_{2} \mathrm{O}_{5}$ ), were sold as pineapple fertilizer in the period $1950-51$. At a price of $\$ 37.50$ per ton for superphosphate, this represents $\$ 32,250$ spent for phosphates in one year. Of course, some minimum amount of phosphate could be useful in mixed fertilizers for pineapples, but a quantity equivalent to 50 pounds of $\mathrm{P}_{2} \mathrm{O}_{5}$ per acre appears to be adequate. If this amount had been used in 1950-51, instead of the old rates, there would have been a saving of $\$ 23,062$ to the pineapple growers.

\section{SUMMARY}

The use of phosphate fertilizers for pineapples has produced the following results in various experiments carried on by this Station:

1. From none to small yield increases were obtained with phosphate used at rates up to 56 pounds of $\mathrm{P}_{2} \mathrm{O}_{5}$ per acre and applied up to 4 months after planting.

2. Yields were depressed when 84 and 112 pounds of $\mathrm{P}_{2} \mathrm{O}_{5}$ per acre were applied.

3. Themaximum quantity of phosphates that could be used for increasing yields under the experimental conditions was 56 pounds of $\mathrm{P}_{2} \mathrm{O}_{5}$ per acre.

4. The depressing influence of phosphates on yields is believed to be due to its action in lowering nitrate intake when carbohydrate and phosphate reserves are ample.

5. High-level phosphate additions serve to hasten pineapple fruiting and produce more culls.

6. At present growers use too much phosphate in their pineapple fertilizer applications, and a distinct saving in money could be realized if rates of phosphate application were lowered.

\section{RESUMEN}

El uso del fosfato para abonar la piña ha demostrado lo siguiente:

1. Las aplicaciones de $\mathrm{P}_{2} \mathrm{O}_{5}$, a razón de 56 libras por acre, a los 4 meses 
de sembrada la piña, produjeron rendimientos insignificantes o relativamente bajos.

2. Los rendimientos decayeron más cuando las aplicaciones de $\mathrm{P}_{2} \mathrm{O}_{5}$ se aumentaron en 84 y 112 libras por acre.

3. Bajo las condiciones de los experimentos, se determinó que 56 libras de $\mathrm{P}_{2} \mathrm{O}_{5}$ fué la aplicación máxima para aumentar el rendimiento de la piña.

4. Se cree que la influencia depresiva de los fosfatos sobre los rendimientos se debe a su tendencia de aminorar la entrada del nitrógeno, cuando las reservas de hidratos de carbono y fosfato son amplias.

5. Las adiciones considerables de fosfato precipitan el tiempo de la florecida en la piña, e inducen la producción de un mayor número de frutas de mala calidad.

6. Actualmente los productores de piña usan más fosfato que lo adecuado, por lo que tienen margen para hacer algunas economías, si disminuyeran las cantidades de fosfato que le aplican a sus piñales.

\section{LITERATURE CITED}

1. González Rios, P., A pineapple fertilizer experiment, J. Dept. Agr. and Labor P.R. 3 6-13, 1919.

2. Henricksen, H. C., Fertilizers: Some pineapple problems, Article 16, Agr. Notes, Federal Exp. Sta., Mayagüez, P. R., 1942.

3. Nightingale, G. T., Potassium and phosphate nutrition of pineapple in relation to nitrate and carbohydrate reserves, Bot. Gaz. 104 191-223, 1942.

4. Pennock, W., Nutrient requirements of pineapples on Bayamón silty clay, Report of the Federal Exp. Sta., Mayagüez, P. R., 62-8, 1939.

5. Samuels, G., Landrau, P., Jr., and Olivencia, R., Response of pineapples to the application of fertilizers, J.Agr. Univ. P.R. 39 (1) 1-11, 1955.

6. Schapelle, N. A., Fertilizer studies with pineapples in Puerto Rico, J. Agr. Univ. P.R. 26 41-60, 1942. 